\title{
大学の研究室における電子情報活動を中心とした諸活動と 物理的環境に関する考察 \\ A CASE STUDY ON THE INFORMATION ACTIVITY AND PHYSICAL ENVIRONMENT IN PLACES OF LABORATORY AT THE UNIVERSITY
}

\author{
渡邊朗 子* \\ Akiko WATANABE
}

\begin{abstract}
Based on the field work for the uses of highly informationalized laboratory at University, this research attempts to clarify various aspects of the activity and character of physical environment with networked information environment. Through the observation of the laboratory and the survey of users' activities, we found several sets of activity, such as gathering, collaborating, communicating, daily-activity including eating and sleeping, and working with computers held simultaneously with others. These activities construct provisionally environmental setting in order to be afforded by the transformation of object, information and event.
\end{abstract}

Keywords: laboratory, activity, information environment, communication, environmental setting, daily-activity 研究室、活動行為、情報環境、コミュニケーション、環境セッティング、生活的行為

\section{1 はじめに}

本論は、「人間一環境系からみた電子情報活動環境のデザインに

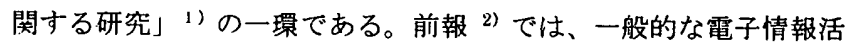
動の諸相と物的環境の特性を明らかにする為に、多様な電子情垠活 動が同一空間で展開される大学のメディアセンターを対象に調查し た。その結果、「たまり」「同期コラボレーション」「スタンドアロ ン」「孤立コミュニケーション」「生活的行為」の5つの主な活動行 為が抽出され、それらが特有の物的環境セッティングを形成してい ることがわかった。また、コンピュータ端末の使用時には、「仮想 着席」「多行為同空間」「多行為同時間」の 3 つの特徵的な諸相が抽 出された。前報では、大学のなかでも学生や教員等多数の人々が多 目的に電子情報活動を行う共有空間であるメディアセンターを調査 対象にしたのに対して、本論では、特定の組織体を形成し、特定の 研究内容と目的をもち、電子情報活動を主な活動の一つとして研究 を行う研究室を調查対象とする。

\section{2 研究の背量と目的}

本論では、実際に高度な情報環境の進展がどのような活動行為 を出現させ、その結果どのような物的環境を形成しているのか、情 報環境が装着された仕事場の特性を明らかにすることを目的とする。
これまで、情報環境を含めた環境と人間に関る基礎的研究は、様々 な分野で盛んに行われてきた。特に、建築計画の分野において、執 務空間としてのオフィスといった限定された空間領域では、度々行 われている。また、大学の研究室を対象にした利用実態からの計画 研究も行われている。しかし、それら既往研究の調査の対象では、 電子情報機器を共用して使用する場合がほとんどであり、情報環境 が必ずしも個々人の活動を支援する環境になっているとはいえない。 それに対して、本調査では、全ての研究室の利用者が、研究室独自 の高速な情報通信ネットワーク網に接続された電子情報機器を持ち、 電子上で組織のほとんどのコミュニケーションや研究活動を行う研 究室を対象とする。建築計画の立場から、このような電子情報活動 を中心にした知的創造の現場を対象に行った研究はまだ少ない。

生態心理学の分野では、E.S.リードが、「人間の環境は選択さ れ変形される環境である」と述べ、さらに、「人間は噮境のなかに ある有限の物、出来事、場から必要な情報を抽出選択し、欲求にあ った物的環境のセッティングを構築しライフの営みを実行すると定 義する」と述べている。リードは、人による環境の修正を「物の変 形」「場所の変形」「出来事の変形」の 3 種類に分類している。

リードの概念は、人間と環境の相互作用から環境デザインの枠組 みを探究する上で、特にデザインの構成要素と方法に関して具体的 


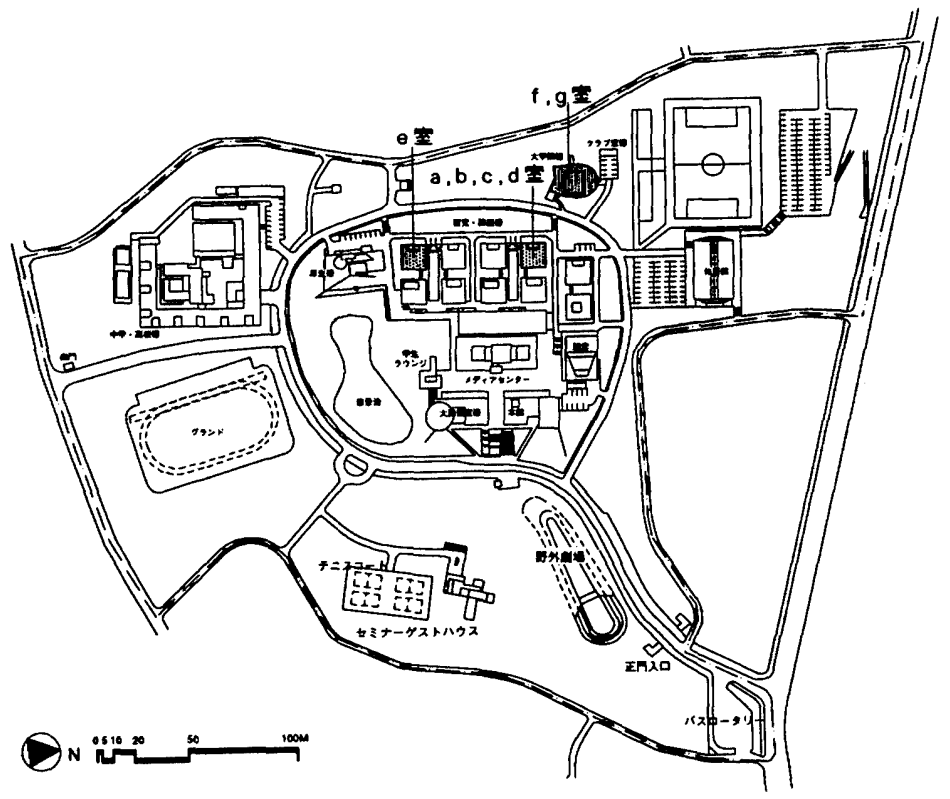

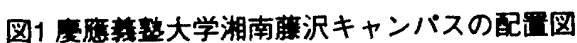

な指針を与えるものである。

本論では、リードの概念を踏まえて、「環境のセッティングとは、 人がある特定の活動をアフォード（提供）するために、物的構成要 素、出来事、場の蔡囲気等から抽出する情報であり、そのなかでも 特に物や空間の原形・操作・変形に関わる情報を物的舆境セッティン グとする」と仮説をたてた。本論では、この仮説をもとに、先端的 な情報通信ネットワーク技術を使いこなし活動する研究組織を対象 に、活動行為、その活動環境の物的構築要素、物的環境セッティン グ、協倾組識の人的構成、情報環境の構築など、活動を取り巻く環 境を各側面からフィールドワークを行う。それによって、情報通信 ネットワークを殹使して活㲜を展開する組織では、どのような諸活 动が行われるのか、その結果どのような物的棵境を楆策するのか、 現状ではどのような問題点があるのか、を明らかにする。それらの 結果から、要子情報活䡃の実態に適した棵境デザインの在り方を研 究する。

最先端の情報化空閂において、全ての研究室利用者が 1 人 1 台以 上のコンピュータと情報通信ネットワークを利用した活功を行う場 合の、人間一噮境系の在り方を、建築学的な立場から明らかにする ことは、今後益々ネットワーク化された菓子情報活動が增加すると 予测される社会的文脈の中で、意義あることと考えられる。

\section{3 时春対象}

調查対象の夏應義塾大学湘南藤沢キャンバス（以下 SFC と略す） は、キャンパス独自の高速な情報ネットワークを持つなど、日本に おいても極めて先端的な情報基盤を持つキャンパスである ${ }^{3)}$ (図 1)。また、SFCは、24時間制キャンパスである。

本研究では、SFC のなかでも最も先端的な情報通信ネットワーク 網を研究室の情報跮境に持ち、研究活動に応用し展開する $\mathrm{M}$ 研究 室 1)を対象に調查を行った。M 研究室は、主に情報通信ネットワ 一ク基盤を対象に研究活動を行う研究室である。

90 年代に台頭した日本のインターネット・インフラの構策と普 及は、この研究室によって研究、推進された。現在でも、研究室に
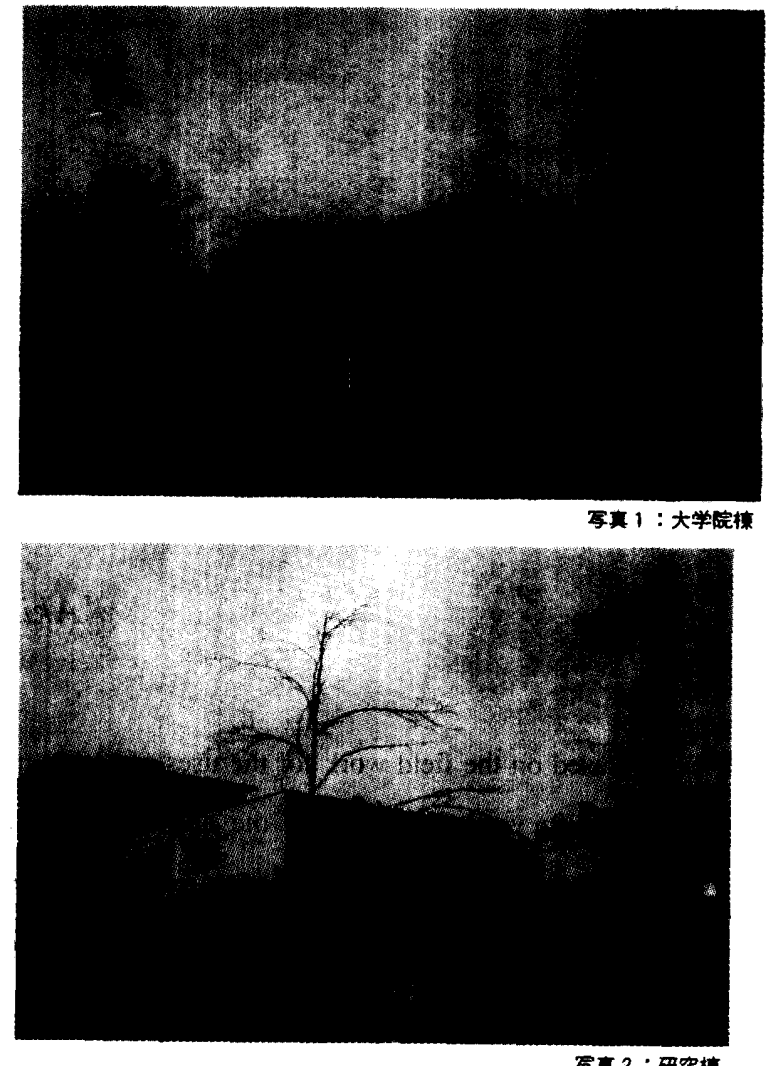

每重 2 ：确究模 は日本と海外を結ぶインターネットのサーバーが設置され、 WIDE ${ }^{5)}$ のオペレーションセンターが併設されている。したがって、 研究室の情報通僖ネットワークにおける情報㻎境は、国内において も極めて先端的であり、一般に普及しているレベル以上に多容量の 情報を高速に受発信することのできる高度なものである。

\section{3-1 研究空の部量}

$\mathrm{M}$ 研究室が活動する 7 つの部屋は、SFC のキャンパスの大学院

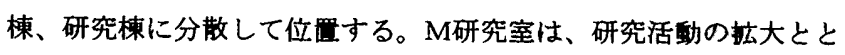
もに、年々研究室を増やしてきた。SFC は、全体的に研究室が不 足しているので、M研究室は空室ができるのを待って、部屋を抬張 してきたため、結果的に分散した配置になっている（図 1 , 写真 1 , 写真 2 , 表 1 \%。7つの部屋の内、2つは事枒用、教授用の部屋で、

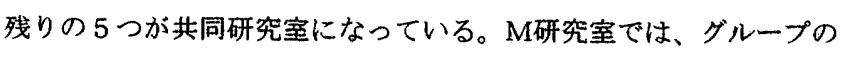
活動を活性化するために研究室の研究テーマを大きく5つに分け、 それらの研究テーマと人の関連性によって、部屋を割り振っている。

\section{3-2 研究至の人的模成}

$M$ 研究室の人的粠成は、教授 1 人、請師 1 人、助手 1 人、研究 員 5 人、博士課程の学生 10 人、修士課程の学生 9 人、学部の学生 約 35 人である。このうち修士以上の学生の数はほぼ固定だが、学 部生の数は、複数の研究室に所属できる教育カリキュラムになって いる為、流動的である。

3ー3 研究至のネットワークとコンピュータ

図 2 に見られるように、M 研究室では、FDDI ${ }^{6)}$ が研究室の基幹 となっており、すべての部瓷に装備され使用されている。また、各 部屋では無線 $\mathrm{LAN}^{7)}$ が常時接続できる状態になっている。研究室 のコンピュータ端末は、全部で 60 台設䁌されている。

\section{3-4 研究宝の情絜伀䔔・共有の方法}

$M$ 研究室では、研究室内部の情報交換はほとんどEメールを中 
表 1 調査対象の研究㦈概要

\begin{tabular}{|c|c|c|c|c|}
\hline 阤屋各埥所 & 面樌住な利用者 & 部屋の主な活轹内容 & たまりのセッティンろ & 情報㻴境 \\
\hline a室研究㨂 3階 & 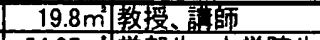 & 教授、諘師の個人研究室 & 持に無し & 光ファイハー、無線LAN \\
\hline b室研究棟3隋 & $54.87 \mathrm{~m}^{2}$ 学部生、大学院生 & 研究開登活動 & & 無線LAN \\
\hline c室研究棟3隋 & $21.7 \mathrm{~m}^{2}$ 常勤の事務員 & 豪筮、マネージメト管理 & 丸型テーブル & 光ファイパー，無線LAN \\
\hline d室研究棟3殂 & $44.73 \mathrm{~m} \mid$ 大学院生 & 研究開発活動，インターネットサーバー設置 & ソファーベッド、テレビ & 光ファイパ二，無線LAN \\
\hline e室研究棟5隋 & $34.56 \mathrm{~m}^{2}$ 学部生、大学院生 & 研究開発活動 & 作業机(細長型) & 光ファイパー，無線LAN \\
\hline 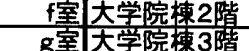 & $\frac{73 \mathrm{~m}^{2}}{4312 \mathrm{~m}^{2}}$ & 研究開發活憅 & こたつ、テレヒ，冷蔵庫 & 光ファイバ二、無線LAN \\
\hline g室大学院棟3階 & $43.12 \mathrm{~m}^{2}$ 助手、大学院生 & 研究開発活動 & ちやぶ台、テレビ、䋐琰 & 半ファイバー 無绪 \\
\hline
\end{tabular}

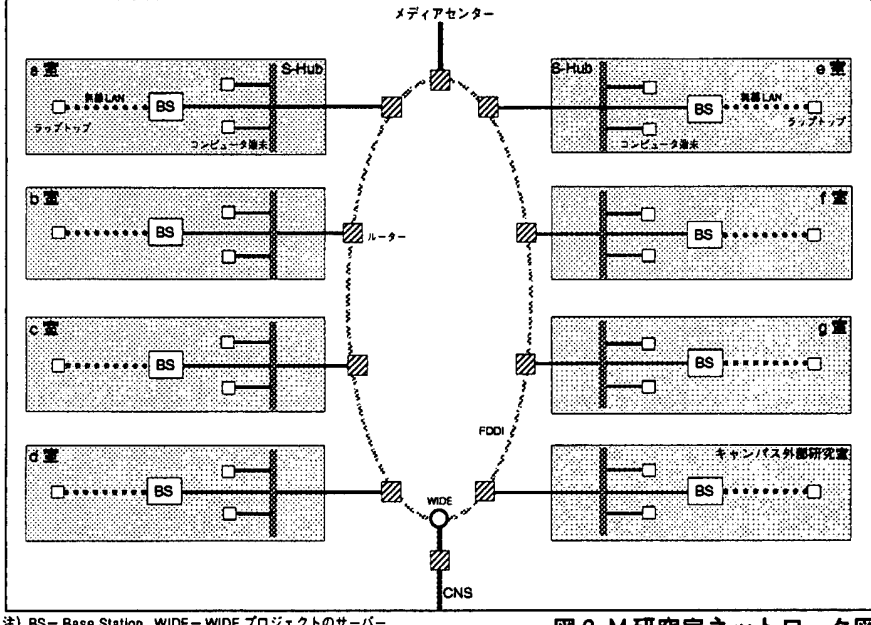

S-Hub-Swith-Hub, C NS- Campus Network System
S-

心に行なっている。WWW ${ }^{8)}$ のホームページは、各研究グループが それぞれどのような活動を行なっているのか、把握するために活用 されている。

\section{4 調查内容と方法}

本研究は、研究室の物的環境に関する実態調査、研究室利用者の 生活行動生態調查、研究室利用者の研究環境に関する意識調查、研 究室の活動実態に関する観察調査、の 4 つの調查から成り立ってい る。

\section{4-1研究室の物的環境に関する实態調查}

図 3 6に見られるように、本調查チーム 9) は SFC のキャンパス に位置するM研究室の 7 つの部屋を対象に、物的環境についてそ の使用実態を調查するために、研究室内の空間の大きさや配置、家 具や備品の内容、大きさ、配置について実測、記録した。

実測調查日：1998 年 1 月 19 日（渱り）

\section{4-2 研究室利用者の生活行動生啋調查}

研究室の学生がどのような場所で、どのような時間帯に、どの ようなメディアを使って、どのような活動をしているのか、を調べ るために、研究室の主な利用者である研究室に所属する 19 人の大 学院生全員を対象に、生活行動生態調查を行った。主に大学で活動 する日を 2 日間ピックアップしてもらい、あらかじめ作成した生 活調查表に、朝 4 時から翌日の朝 4 時までの 24 時間、どこで、何 を使って、誰と、何のために、何をしていたか、について活動の際 随時記入してもらう方法でアンケート調查を実施した。図 7 に見ら れるように、研究室に所属する 19 人の大学院生全員にアンケート 用紙を配布したところ、9人から回答が得られた。

調查日：1998 年 1 月 19 日（配布）～同年 1 月 30 日（回収）

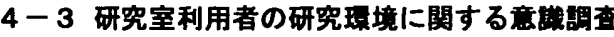

研究室利用者の生活行動生態調查で回答の得られた $\mathrm{M}$ 研究室の 9 人に対して、日常的な生活の様子や研究環境に対する意識につい

\begin{tabular}{|c|c|c|c|c|c|c|c|}
\hline 特品部㢄名 & a 童 & b童 & c窒 & $d$ 空 & $\theta$ 室 & f 量 & $\mathrm{g}$ 포 \\
\hline 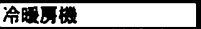 & 有 & +3 & 旬 & 2 & +1 & 勾 & 司 \\
\hline 加湿器 & 0 & 0 & 0 & 1 & 0 & 0 & 0 \\
\hline 會藏成 & 0 & 1 & 1 & 1 & 1 & 1 & 1 \\
\hline コーヒーメーカー & 1 & 1 & 1 & 1 & 1 & 1 & 1 \\
\hline オーフンントースター & 0 & 1 & 1 & 0 & $\underline{0}$ & 0 & 1 \\
\hline 㰠敛器 & 0 & 1 & 0 & 0 & 0 & 0 & 1 \\
\hline 洗面世 & 五 & 司 & 司 & 無 & 無 & 無 & 㷊 \\
\hline ソファー & 0 & 0 & 0 & 4 & 0 & 1 & 0 \\
\hline こたつ & 0 & 0 & 0 & 0 & 0 & 1 & 0 \\
\hline ベット & 0 & 0 & 0 & 1 & 0 & 0 & 1 \\
\hline 好 & 5 & 14 & 4 & 6 & 10 & 9 & 13 \\
\hline 本细 & 4 & 9 & 2 & 3 & 10 & 8 & 13 \\
\hline ホワイトボート & 1 & 1 & 0 & 0 & 0 & 0 & 0 \\
\hline コンピュータ保器 & 2 & 11 & 4 & $4^{\text {(3⿻4一𠃋 }}$ & 12 & 15 & 12 \\
\hline$コ と-$ 㙨 & 의 & 1 & 1 & 0 & 0 & 0 & 0 \\
\hline E估挠 & 2 & 2 & 2 & 2 & 2 & 1 & 2 \\
\hline ファックス & 0 & 1 & 0 & 0 & 0 & 2 & 1 \\
\hline ブリンター & 1 & $\underline{0}$ & 1 & 1 & 1 & 2 & 0 \\
\hline テレビ & 0 & 0 & 0 & 2 & 0 & 0 & 1 \\
\hline
\end{tabular}

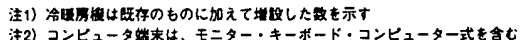

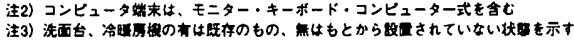

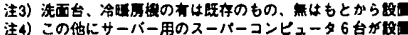

て調査するために、研究内容、平均的な睡眠時間、誰とどこで夕食 をとるのか、家の情報環境を使っての仕事の有無、研究室の環境に 対する満足、不満足など 11 項目の質問に対して、アンケート用紙 に記入回答してもらう方式で行った。表 $3 に$ 見られるように、調查 の結果、9人中 8 人より有効回答が得られた。

調查日：1998年 1 月 30 日（配布、回収）

\section{4-4 研究室の活的实能に関する银宗調查}

研究室内の一日の利用状況、活動行為、コミュニケーションや休 息の取り方など、活動実態をより詳しく調べるために、コラボレー ションの適性人数と相互コミュニケーションが無理なく行われる規 模を持つ $\mathrm{g}$ 室 ${ }^{10)}$ (表 1）を対象に、11:00 から 21:00 まで ${ }^{11}$ ) 観察、 記録した。フィールド調查の開始時から終了時までの間、ビデオ 2 台を、 $\mathrm{g}$ 室の 2 つの角に固定して設置し、室内の出来事や人の行為 を記録撮影した。観察調查の時間を 8 ラウンドのタイムテーブル に分けて ${ }^{12)} 、 30$ 分おきに研究室内の人の分布位置関係をあらかじ め作成したプラン用紙に鉛筆でプロットする方法で記録した。さら に、活動行為について詳しく調査するために、観察記録者はカメラ を使って、研究室の人の行為を適宜撮影した。

フィールド調查日：1998年 4 月 21 日（晴れ）

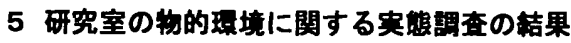

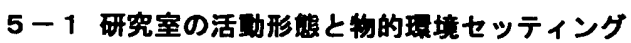

研究室の物的環境に関する実態調查の結果、7つの各部屋から「コ ンピュータ作業のセッティング」と「たまりのセッティング」の 2 つの物的環境セッティングが抽出された。

図 3 6 を見ると、M 研究室では、どの部屋にも机の上に置かれ たコンピュータを使って作業を行う「コンピュータ作業のセッティ ング」 ${ }^{13)}$ が複数確保されていることがわかる。「コンピュータ作業 のセッティング」には、図 3,4 に見られる $\mathrm{c}$ 室、e 室のように室内 

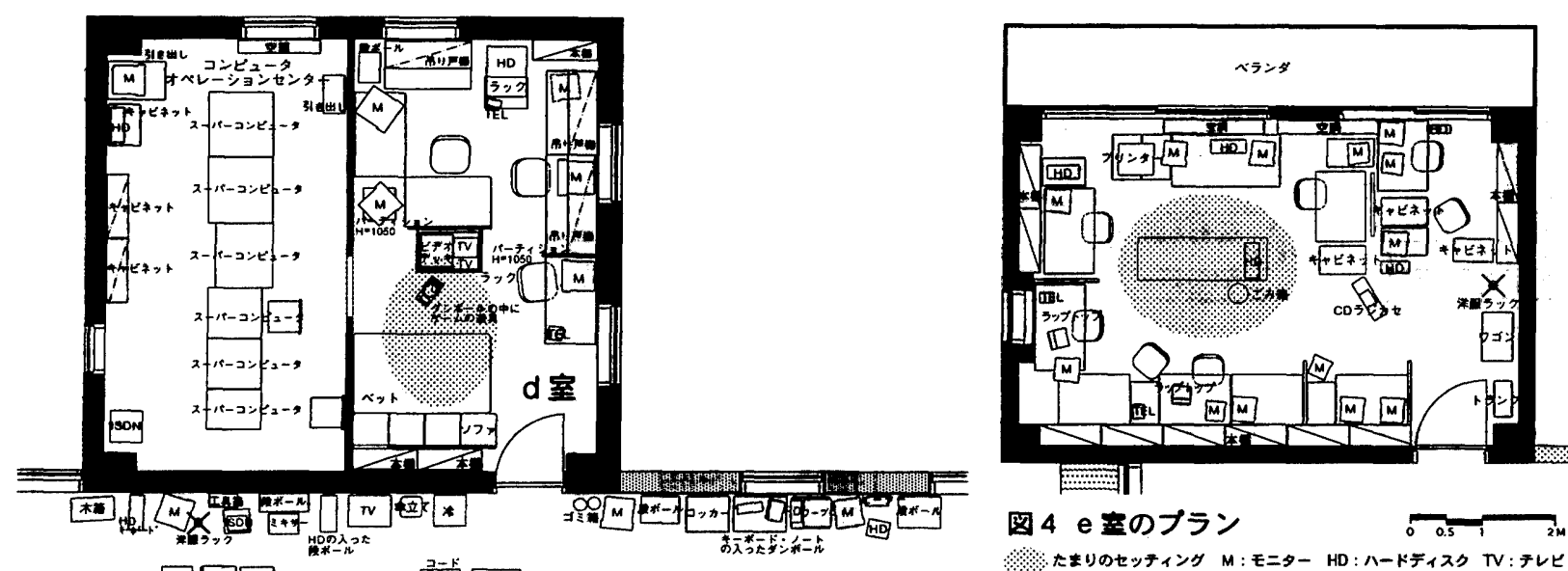

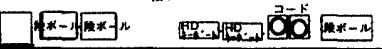

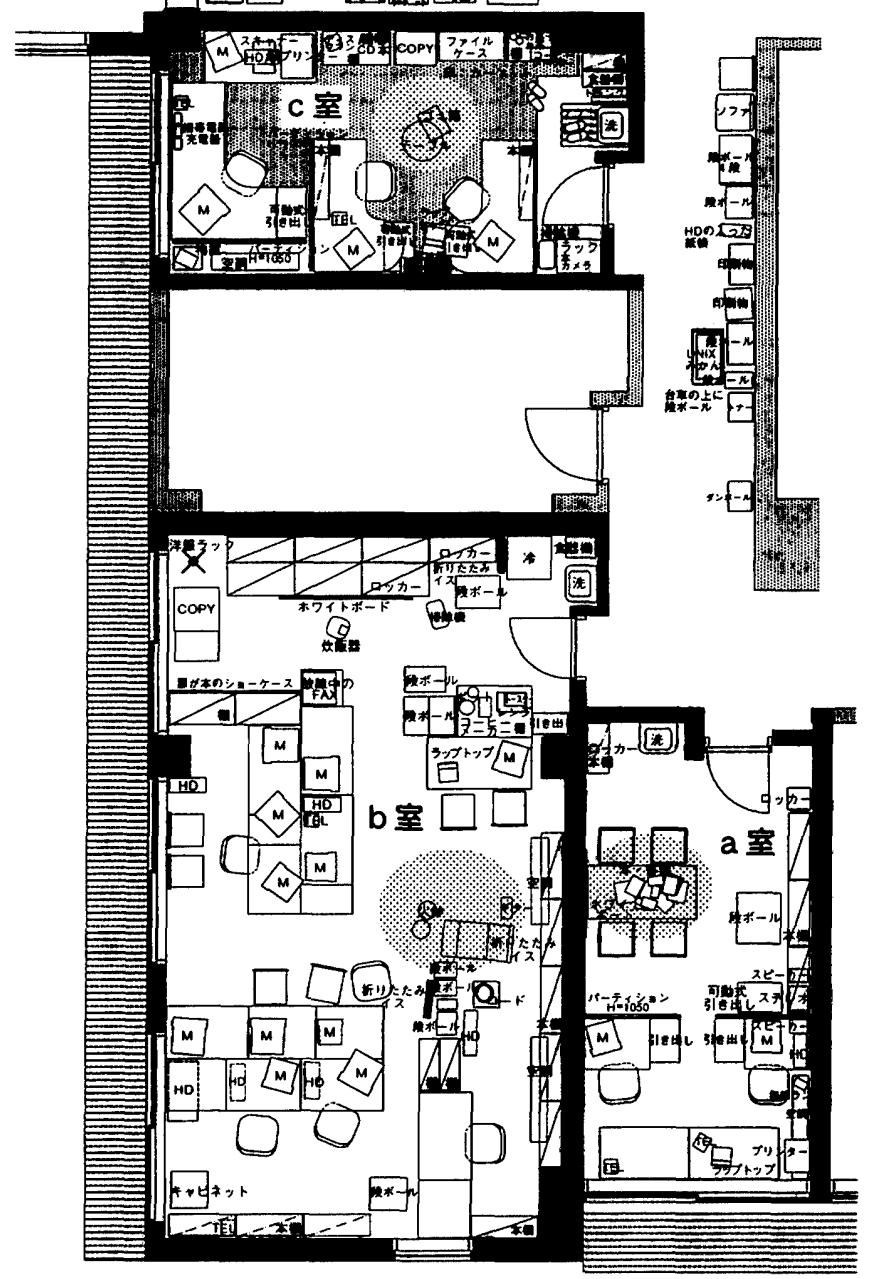

図 4 e 害のブラン

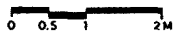

\%たシりのセッチィンタ M:モニター HD:ハードティスク TV: テレヒ

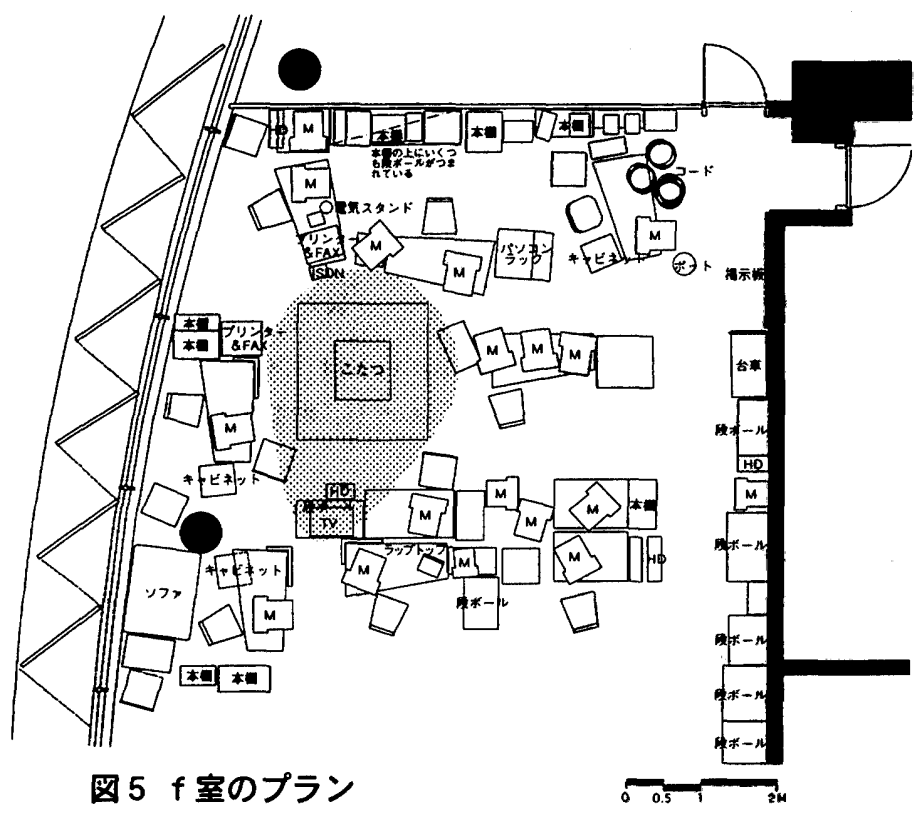

图 $3 \mathrm{a}$ 室、b 室、 $c$ 室、 $d$ 室のプラン 0 0.5 たたりのセッティンク M:モニター HD:ハードティスク TV: テレヒ

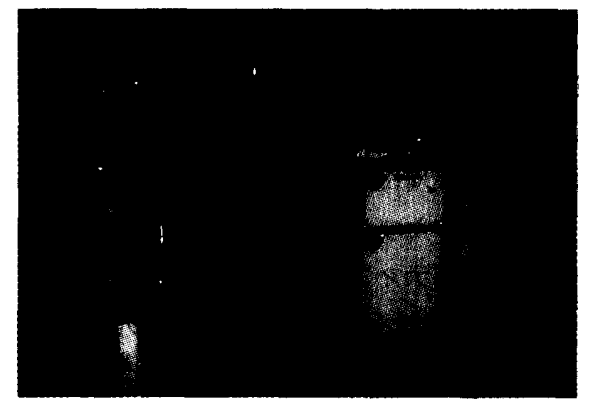

写真 3 研究室の痛下に出された物品

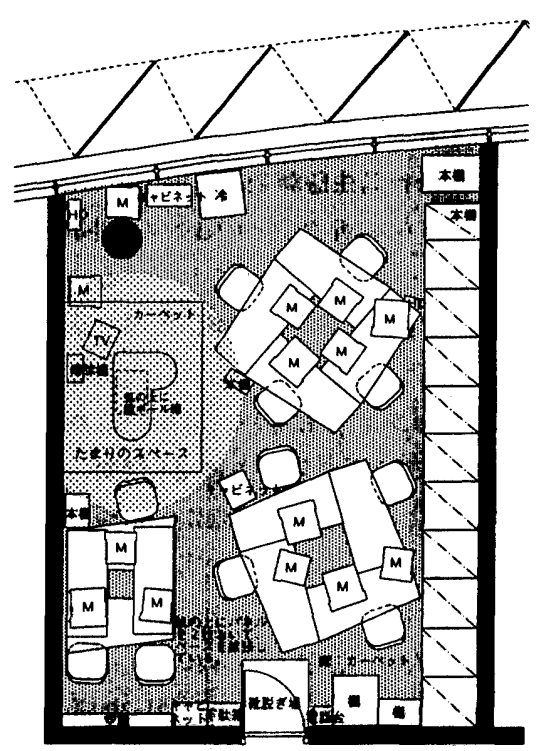

图 $6 \mathrm{~g}$ 室のプラン

たまりのせッチィンク M:モニター HO:ハードチィスク TV:チレヒ 
の人の活動を囲み込むように壁に沿って机とコンピュータを配置す る「活動包囲型配置」や、図 3,6 に見られる $\mathrm{b}$ 室や $\mathrm{g}$ 室のように机 と机を向かい合わせに配置する「対向型配置」、図 5 のf室のよう に無秩序に分散して配置する「分散型配置」などそれぞれ異なる夕 イプがみられた。また、図 3 6 に見られるように、各部屋には、 こたつやちやぶ台、ベッドなどが設置され、床座や手足を伸ばす姿 勢を可能にする「たまりのセッティング」14) がみられる。また、 その周辺にはテレビや楽器がある場合もあり、娛楽の行為が手短に 行なえる物的環境セッティングになっている。

\section{5-2 研究室の椎成要素}

表 2 を見ると、研究室の各部屋には、冷蔵庫やコーヒーメーカー、 オーブントースターなど飲食に関る機器がそれぞれ設置されている ことがわかる。中には、炊飯器がある部屋もあり、研究室内で、飲 食の行為が行われる現状が明らかになった。

また、表 2,図 3 6 からは、M 研究室ではベッドやデレビ、こた つ、ソファーといった本来の電子情報活動を目的とした支援家具だ けではなく、どちらかといえば休息を目的とした家具や機器も、同 空間に導入されていることがわかる。これらは、研究活動を行う空 間で同時に休秘や気分転換を行うことを促進している。

\section{5-3 不使用の物品と眝视庫}

図 3 ,写真 3 を見ると、研究室内には、資料をつめたダンボール や普段使わないコンピュータ機器や雑貨が、室内のいたるところに 置かれている。特に、研究棟の $\mathrm{M}$ 研究室の廊下には、不使用であ るが捨てられないテレビや泠蔵庫などの家電、コンピュータ機器、 ダンボールなどが壁づたいに陳列されている。これらは、現時点で 活発に使用していないだけであって、廃棄物ではないので、捨てら れない状態にある。また、物によっては、現時点で研究室に置いて おく必要はないが、今後またすぐ使う予定があるものもあり、必ず

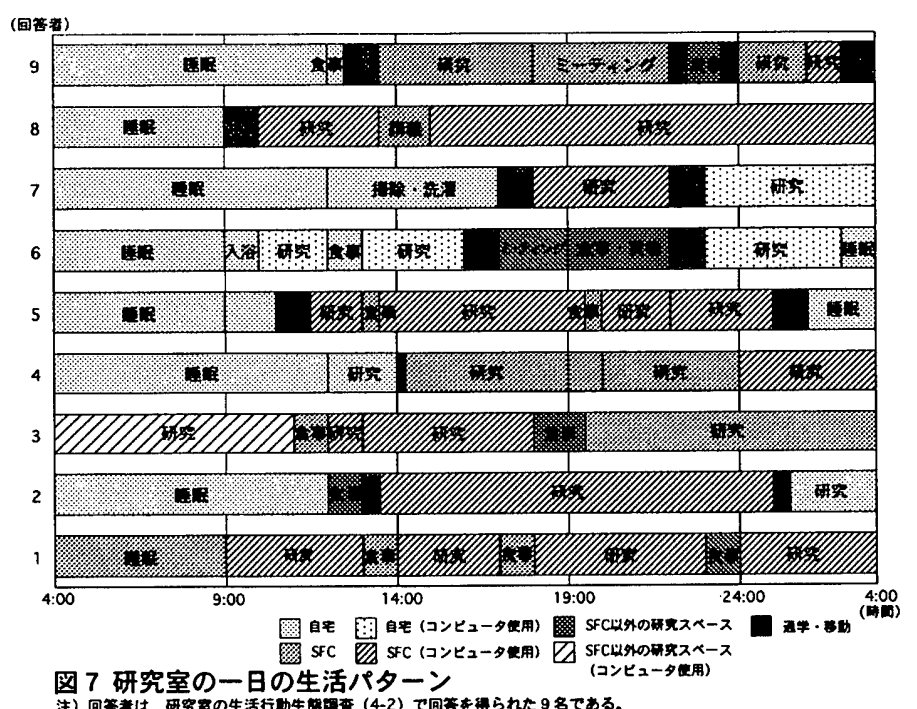

しも倉庫にしまった方がいいものとも限らない。これは、活動の過 程で常時出される様々な不使用の機器や資料を一時的に㯰いておく、 十分な保管所が確保されていない実状を反映している ${ }^{15.5}$ 。

\section{6 研究室利用者の生活行功生㗭調查の結果}

研究室利用者の生活行動生態調查の結果、研究空の利用者の生活 パターンについて以下のことがわかった。図 7 を見ると、全般的に 午前中は睡眠をとっているケースが多く、起床が正午前後で、午後 から研究活動を始めるケースが多い。大学の研究室での研究活動 は、夜中から明け方まで続けられるケースもある。また、自宅に州 宅してからコンピュータで研究を行っているケースも図 7 にみられ た。図 7 の $1 ， 3$ の回答者のケースは、24 時間中自宅に一度も戻 らずに、大学で研究活動を続けている。

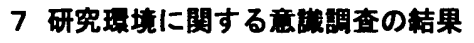
7-1 研究案利用者の生活の様子

研究環境に関する意識調查からは、自宅の情報環境を使って仕事 をする人は、8人中 7 人が「する」と回答している。自宅の情報 環境を使って仕事をする」と回答した人も、日中から夜にかけては、 大学でミーティングに参加したり、研究活動を行っている。表 3 を 見ると、夕食に関しては、8人のうち 6 人が「友人や研究室の仲間 と一緒に外食をとる」、4人が「一人で自宅で食べる」という回答 が得られた。睡眠時間については、最も短い睡眠時間の回答は「3.5 時間」、最も長い睡眠時間の回答は「8時間」、そのなかでも「8時 間」程度の回答が最も多かった。最も短い睡眠時間を回答した人は、 研究室への不満点として「学生が仮眠できる宿泊施設が（大学に） 欲しいとと回答している。

\section{7-2 研究窒利用者の满足·不满足}

さらに、M研究室の研究環境に関する意識調查からは、以下のよ うな結果も得られた。表 3 を見てみると、研究室の全般的な環境に 対しては、8 人中 5 人が「満足」と回答している。特に情報環境に 対して不満足な点を上げた人は少なかった。一方、不満点には、机 の大きさ、部屋の狭さ、収納の少なさ、各研究室の距離の遠さなど 物的環境に関するものが多かった。

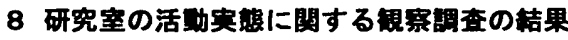 8-1 研究室の一日の利用状況}

$\mathrm{M}$ 研究室の活動実態に関する観察調査では、一日の活動実態がより 詳細に観察された。図11に見られるように、午前中は研究室の利用者は 少なく、13時半頃から利用者が段々増えコンピュータやラップトップで作 業を行い、その後 17 時に他の部屋でミーティングがあるため一気に人数 が减少し、18時半過ぎには残りの利用者も夕食に出かけたため一旦研 究室は空室になった。19時半には、夕食に行った利用者が部屋に戻り 表3 M研究室の研究環境に関する意識調査結果

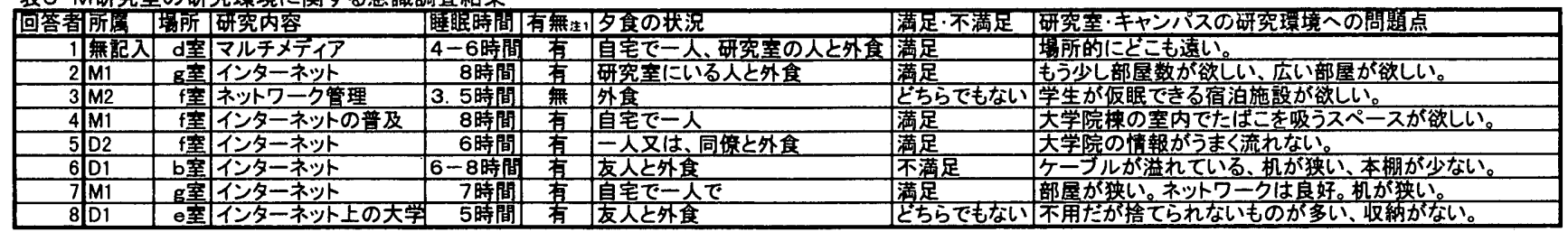

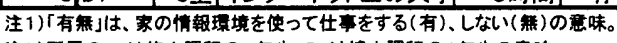

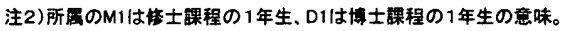




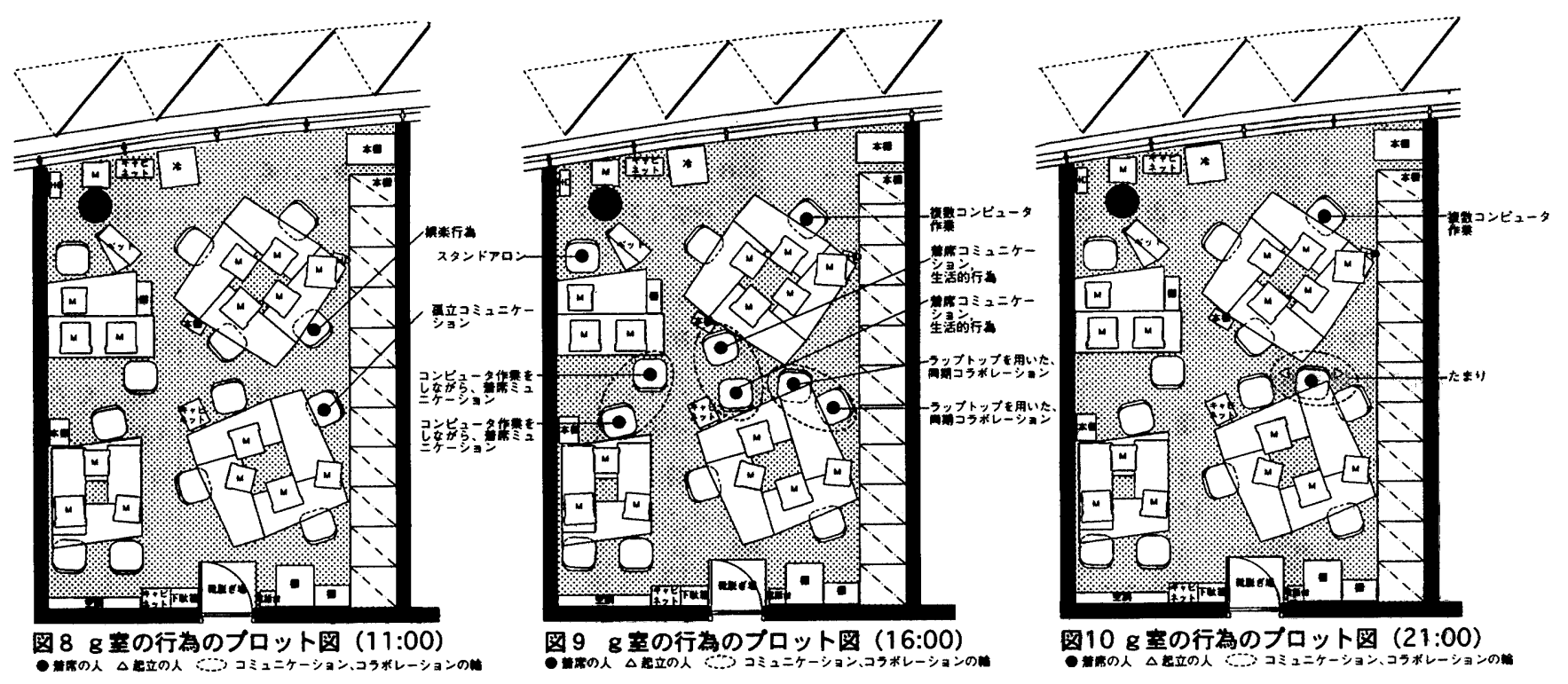

コンピュータに向かい作業を再開した。

プロット調查は、21時で終了したが、調查の翌日、利用者に行ったヒ ヤリングによると、その後、21時過ぎにミーテイングを終えた利用者が部 屋に㞔り、一時的に部屋が満室状態になり一斉にコンピュータ作業が始 まった。それ以降は、少しつうつ利用者が州宅し始め、最後の利用者が部 屋を出たのは翌日の午前3時半であった。調査日には、宿泊した者はい なかったが、研究活動を夜中に行って研究室に摍泊するケースもあり、 多いときには1週間家に懦らず研究室に寝泊まりする者もいるという。そ の場合、利用者は研究室の机の下に垵転がって仮眠をとる。

\section{8-2 研究室の活的行为}

さらに、活動実態に関する穓察調查からは図 8 10に見られるような 研究空の活動行為が抽出された。メディアセンターの調査でみられた「た まり」、同期コラボレーション」、「スタンドアロン」、孤立コミュニケーショ ン」(写真5)、「生活的行為」(写真4)の他に、「着席コミュニケーション」 (写真6)「複数コンピュータ作業」(写真7)「娛楽行為」(写真5)のそれぞ れの行為が確認された。

「たまり」は、複数の人が集まってコミュニケーションをとるかたちで形成 される。同期コラボレーション」では、コンピュータのモニターを誢き込む ような姿勢で $2-3$ 人の小人数でコラボレーションが行われる。 CD や MD をへッドホンで開きながらコンピュータ作業を行う「スタンドアロン」は、利 用者の中によく見られた。また、室内に常設している電話を使わないで 自分で所有している搭带菓話を介して外部とコミュニケーションを行う「孤 立コミュニケーション」もみられた(写真5)。コンピュータ作業を行いなが ら飲食をとる「生活的行為」も見られた(写真4)。それらの行為は、ワーク ステーションに向かった椅子に着席しながら行われている。

その他に、害席しながら会話を介して同室の利用者とコミュニケーショ ンを行う行為がみられた。著席したまま会話などを介して他者とコミ ュニケーションをとる行為をここでは、「着席コミュニケーショ ン」と名付けることにする。写真6に見られるように、利用者は、コン ピュータ作業を行いながら、或いは、椅子に座ったままお互いの顔を見 合わして、会話を中心にした「着席コミュニケーション」を行う。また、各利 用者の席と使用するコンピュータは、ある程度決まっている。写真7のよう に、研究室で仕事を行うときは、端末の他に、ラップトップなど複数のコン ピュータを機動させてそれらを同時に行き来しながら活動する行為もみら

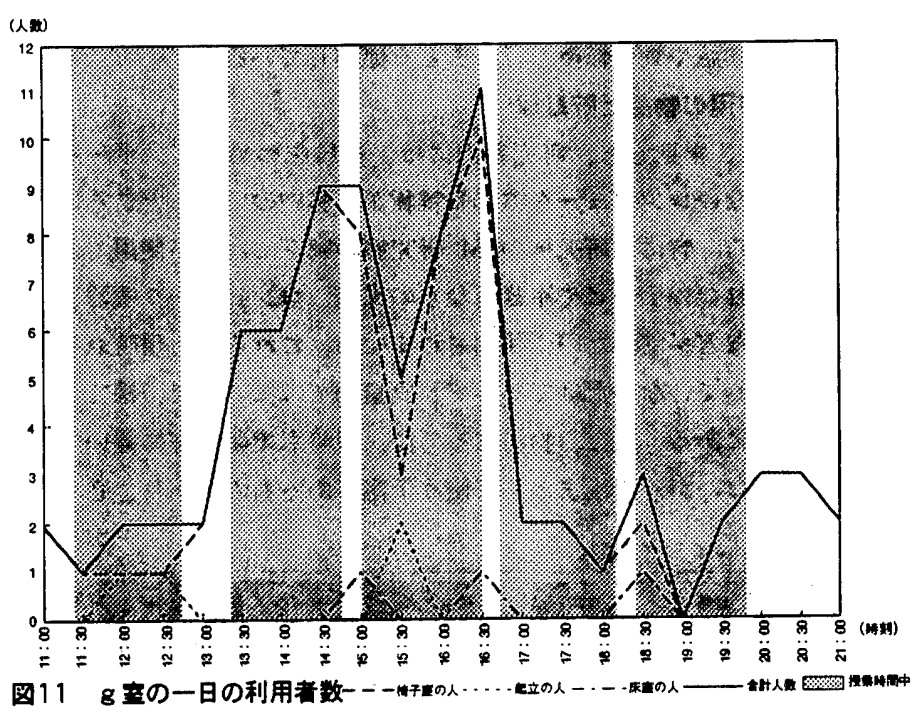

图11 $\mathbf{g}$ 定の一日の利用者数

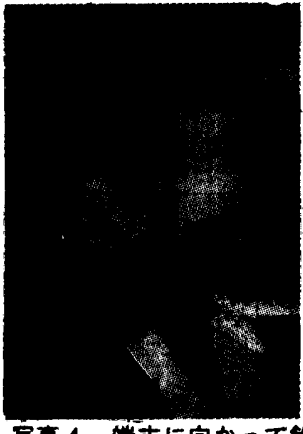

写兵4 此末向かって飲 金をする生活行為

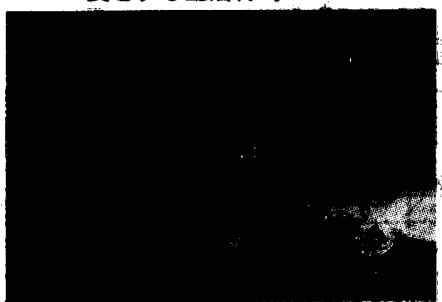

軍真 6 㮍席コミュニケーション

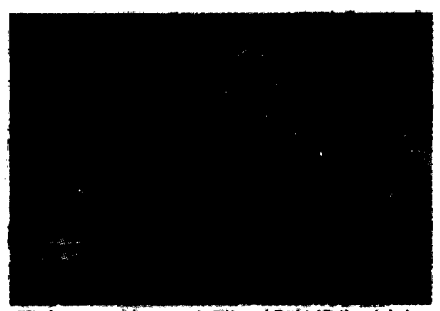

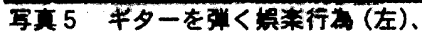

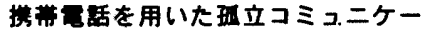
ション

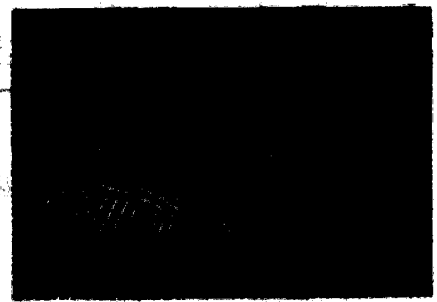

写㫷 7 褀コンピュータ作举 
れた。ワークステーションやラップトップなど複数のコンピュータ を同時に行き来しながら作業を行う行為をここでは、「複数コンピ ユータ作業」と名付けることにする。さらに、写真5のように、楽器や 道具を使って娛楽を行う行為もみられた。楽器や道具を用いて行う娛 楽的要素の強い行為をここでは「娛楽行為」と名付けることにする。 以上のように研究室では、同空間に多様な行為が展開する「多行為同空 間」の諸相が明らかになった。

8ー3 研究室の活娌とコミュニケーション

活動実態に関する観察調査で行ったビデオ観測の結果から、研究室 の利用者の行動は、非常に継続時間が短く、3-4 秒で行動が切り替わる ことも稀でなく、異なる行為をほぼ同時に行っている様子が伺えた。研究 室での活動の様子をさらに詳しく調査するために、4時間以上研究室に 泍在した利用者を 1 人ピックアップして、図 12 のダイヤグラムを作成した。 その結果、利用者がコンピュータや資料などを使って研究を行いながら、 会話によるコミュニケーションや飲食などの諸行為を同時に平行して行う 「多行為同時間」の諸相が明らかになった。

\section{8ー4 たまりのセッティング}

活動実態に関する観察調查を行ったg室は、図6に見られるように、約 3ヶ月前に環境の実態調查を行った時点では、ちゃぶ台、テレビ、絨毯 によって構成された「たまりのセッティング」が室内に設けられていた。し かし、図8のように、研究プロジェクトメンバーの再編成により同室の利用 者が新たに加わることになったため、「たまりのセッテイング」は撤去され、 代わって机とコンピュータが設置された。このレイアウトと物的環境セッテ イングの変化について利用者 6 人に対してヒヤリングを行ったところ、「(た まりのセッティングが)なくなってさみしい、あった方が良かった」と回答し た者が5人いた。一方、「(あってもなくても)あまり変わらないりと回答した 者は1人であったが、その利用者はこの部屋を頻繁に使う利用者ではな かった。あった方が良かった」と回答した理由には、「たまりのセッティン グで仮眠をとったり、研究の合間にテレビゲームをすることができた」「他 の部屋で研究している者が(たまりのセッティングを求めて)遊びに来た」 「研究室に宿泊しないで䚻宅するようになった」などがあった。

以上のことから、電子上でほとんどの組織の情報伝達、交換、研究活 動を行う組織において、物的な「たまりのセッティング」が、研究活動以外 の休息や物理的なコミュニケーション、娛楽の行為を行う場として重要な 役割を持っていることがわかった。

\section{9 まとめと考察}

\section{9-1 研究室の賭活轵行為と珢境セッティングの特性}

研究室で見られた活動行為は、メディアセンターでも見られた「たまり」 「同期コラボレーション」「スタンドアロン」「孤立コミュニケーション」「生活 的行為」の他に、着席コミュニケーション」「複数コンピュータ作業」「娛楽 行為」が確認された。また、ビデオ観察から、利用者がコンピュータに向 かって研究活動を行いながら、飲食やコミュニケーションなどの行為をほ ぼ同時に行っており、メディアセンターでもみられた「多行為同空間」「多 行為同時間」の諸相が確認された。

研究室でみられた活動行為では、家具の移動や電子情報機器の使 用、コミュニケーションの発生など、物、場、出来事の変形によって、活動 をアフォードする環境を仮設的に形成しているケースがみられた。例えば、 図9に見られるように、「着席コミュニケーション」の活動行為では、研究室 の利用者は本来の目的である研究活動のためにコンピュータ端末に向

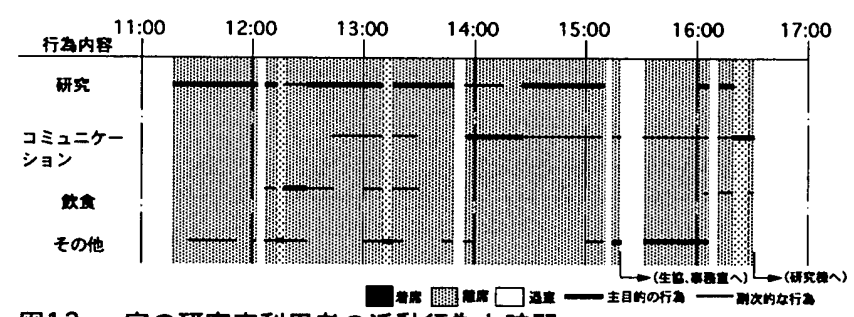

图12 $\mathrm{g}$ 室の研究室利用者の活動行為と時間

かって作業をしながら、あるいは、椅子の向きを変更することで同室空間 に居る人とコミュニケーションをはかっていた。これは、言葉による「出来 事の変形」や家具の移動による「物の変形」によって、仮設的にコミュニケ ーションをアフォードする環境を形成している例である。また、「孤立コミュ ニケーション」では、携帯電話での通信が遠方の他者とのコミュニケーシ ヨンを成立させる仮設的な環境のセッティングになっている。「生活的行 為」や「同期コラボレーション」では、家具を移動したり配置を変えたりする ことで、物的環境セッティングを変形し、それらの行為ができる環境を確 保している。このように、研究室の利用者は、「多行為同空間」「多行為同 時間」の電子情報活動の諸相に合わせて、それらの活動をアフォードす る環境のセッティングを、物や情報環境や出来事を操作することによって、 仮設的に構築している。

このように電子情報活動環境では、仮設的に構筑され変化する活動 行為とセッデイングの特性を踏まえて、物的環境がデザインされることが 望ましい。例えば、孤立コミュニケーションをより行いやすくするよう隔離さ れた領域を室内の片隅に設置する、着席コミュニケーションを可能にす るよう空間に連続性を持たせ、可変可能なレイアウトにする等が考えられ る。

\section{9-2 保管所の都目}

また、本論で調查したM研究室は、現時点で不使用である物品 が廊下や研究室に溢れていた。研究環境への不満点としても、部屋 の狭さや収納の少なさが指摘された。このことから、電子情報を中 心に創造活動を行う現場でも、全てが電子化されるわけではなく、 活動の過程で収集した物、知識や情報を貯蔵したり、情報知識の創 造プロセスによって生み出された物、情報、知識を一時的に保管す る保管所が仕事場に隣接するところに必要であることがわかった。

\section{9-3 研究室のたまりのセッティング}

研究室の環境に関する調查では、キャンパスの中で分散された7つの $\mathrm{M}$ 研究室のレイアウトは、それぞれ微妙に異なっているものの、主に個 人的にコンピュータ活動を行う「コンピュータ作業のセッティング」と「たま りのセッティング」の2つのセッティングで構成されていることがわかった。 「コンピュータ作業のセッティング」には、「活動包囲型配置」「対向型配 置」分散型配固」の3つのタイブが観察された。

「たまりのセッティング」は、各部屋に一つづつ設置されていた。「たま りのセッティング」はメディアセンターでもみられたが、本調査か ら、電子上で組織のコミュニケーションや研究活動が活発に行われる研 究組織でも、机やソファー、ちゃぶ台など特有の家具、機器を用いて固 定的な物的環境セッティングによる「たまりのセッティング」を形成している ことが明らかになった。研究室の利用者は、電子情報活動の合間に「た まりのセッデイング」で人との物理的なコミュニケーションを求めて集まった り、気分転換のためにコンピュータから離れて、本来の研究活動の行為と は異なる「たまり」「生活的行為」「娛楽行為」など電子情報活動以外の諸 
行為を行っている。

\section{9-4 生活的行为のセッティング}

研究室内では、飲食の行為や宿泊が行われるなど生活的行為が日常 的に行われているため、それらの行為を支援する物品や機器が常設さ れていた。これらから、情報活動を中心に行われる研究活動の過程 において日常の生活的行為が研究の場に持ち込まれて、固定的な物的 㻖境セッテイングを形成していることが明らかになった。

今回調查を行った SFC のキャンパスは、 24 時間制の大学であるため 学生は 24 時間好きな時に研究室を利用することができる。また、研究室 では、メディアセンターと異なり、学習の場というだけではなく、共通の目 的を持って特定の研究を行う組織と場が形成されている。こうた条件が、 学習、研究や仕事の時間带を、昼間だけではなく、夜中にまで延長可能 にし、学習・研究・仕事と生活が自然に融合しがちな傾向を招いていると いえる。

キャンパスのように24時間制で複合的機能を兼ね備えた仕事場は、 そこが研究開発の行われる現場であることから、生活の場と生産の場が 踏合した知的創造の仕事場としての在り方を提示する。今後も、特に知 的創造が行われる研究開発など知的頭脳労伹に関わる仕事場では、生 活的行為をアフォードする物的罢境のセッティングを㮴極的に取り入れ ることが望ましい。

\section{0 おわりに}

今後は $\mathrm{SOHO}^{16)}$ や情報産業系の組織などを対象にした䉓子情報 活䄭環境の事例についても調查研究を行っていきたい。また、本論 の結果やそれらの調査結果に基づいて、今後の環境デザインの在り 方を具体的に提案し、現状をより改善するような環境デザインの方 法を、実呀、検証することから、人間一德境系からみた菓子情報活 功壊境のデザインに関する研究をさらに進める予定である。

尚、本論文については、日本女子大学・小谷部育子教授、新潟大 学・高橋鷹志教授、慶應義塾大学・奥出直人教授にご教示、ご指迸 賜った。記して感謝の意を表したい。

注颗

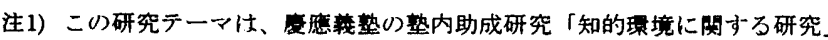
の主要研究テーマのーつである。自然棵境、社会環境、人工物環境、

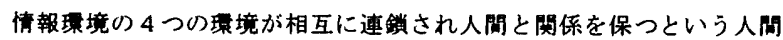
一環境系けデザイン概念をもとに、实祭に西子情報機器やネットワー クなどの情報璄境を創造的な活動や研究開発の知的活動に応用してい

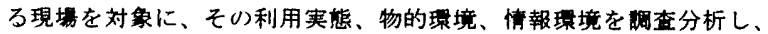

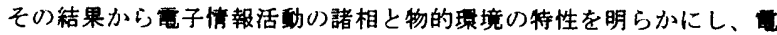

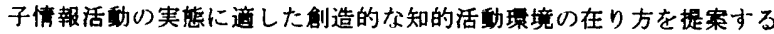
ことを目的としている

注2）本論文隹、先の論文「大学のメディアセンターにおける利用者の曹子

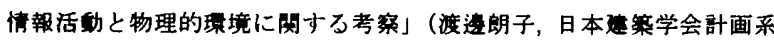
論文集, 1998.8, No.510,p.147-154）の緌絽である

注3）通倍回線速度：10Mbps-100Mbps，稳動コンヒュータ数：4070 台（学 部：3083 台、大学院：987 台/1998 年 4 月 22 日現在）

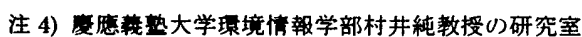

注 5) Widely Integrated Distributed Environment U)略，1988 年から村井
純教授を中心に始末ったネットワーク棬築の産学共同ブロジェクト 注 6) Fiber Distributed Data Interface の略。被数のサーバーとワークス テーションを結ぶ双方向リング機棬、光ファイバーのこと

注 7）無線を用いてネットワーク接繶を行うシステム。

注 8) World Wide Webの略、インターネットに接繶された世界の中のコン ヒュータ上で公開されている情報を自由に利用、参照寸るシステム

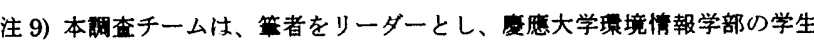
3 名、同大学大学院政策・メディア科の大学院生 2 名、計 6 名で楼成 注 10) $\mathrm{g}$ 室は、学部生 9 人、大学院生 7 人、助手 1 人の 17 人で權成寸るモ バイルコンビューティングに関して研究するチームによって使用されて いる。これはC.アレキサンダーが最も効率的で仕草の满足感が得られ る規模としてあげている 5 人から 20 人の組織㭗成にあてはまる。（C． アレキサンダー：ハターンランダージ,鹿圕出版会,1984,p209）また、 $\mathrm{g}$ 室の室内の幅は、 $7.7 \mathrm{~m}$ と $5.8 \mathrm{~m}$ であり、これは、エドワード・ホール が無理なく相互のコミシニケーションが行われる規模と提唱した約 $9 \mathrm{~m}$ 以下である。（E.ホール：かくれた次元,み寸ず萧房,1970,p176）

注 11) 本調查チームは、 $\mathrm{g}$ 室の活動実態に関する調查の内容を計画するため に、 $\mathrm{g}$ 室の管理者である助手に、あらかじめ日常的な研究活動の時問带 や様子などについてヒヤリングを行った。その結果、日常的にg 空で活 動が行われる時間带が主に 11:00-21:00 であることを閣き出し、フィー ルド郮查の時閒带を11:00-21:00に決定した。

注 12) 全部で 8 ラウンドに分けて、各ラウンドごとに稓察釷録者が 1-2 人常 時 $\mathrm{g}$ 室に居て、利用状況を钼察、記録した。第 1 ラウンド：11:00-12:40, 第 2 ラウンド : 12:40-14:10, 第 3 ラウンド 14:10-15:40, 第 4 ラウンド : 15:40-17:10, 第 5 ラウンド : 17:10-18:40,第 6 ラウンド: 18:40-20:10, 第 7 ラウンド : 20:10-21:40, 第8ラウンド : 21:40-23:00

注 13）机、椅子、コンビュータなどコンヒュータを使って作業を行うための 物的環境セッティングのことをここでは「コンビュータ作業セッティン ク」と名付けることにする。

注 14) 人々がコミュニケーションやグループ作業をすることを可能にする物 的環境セッティンク（先の論女 2）を参照）

注 15）大学の會庫を管理している総務担当者の話によると、キャンハス内の

合落は常に满杯状態にあるという

注 16) SOHO とは、Small Office Home Office ひ略語である, 小さな率務所

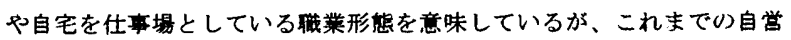
業やフリーランサーと異なり、バンコンやネットワークという情報通借 技術を取使することで空開的な制約を超え、ビジネスやその他の諸活動 を展開する

\section{接文神}

1）山田哲弥：執務空間における領域に関する研究一空闑共用の建策計画的 考察，学位論文, 1995

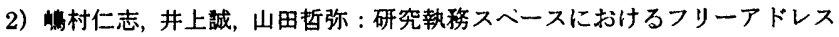
ニーザー評価に関寸る研究，日本建築学会計画系諭文集，第 483 号， 1996.5, p.159-168

3) E.S.REED : Encountering the world: Towards an ecological psychology, Oxford University Press, 1996,p.111-125

4）日本情報処理開発協会編：情報化白書,コンビェータ・エージ社，1998， p. $170 \cdot 172$

5) 半田智久：知能棵境埨， NTT 出版, 1996, p.176-190 